$10 \mathrm{IKC}-280$

\title{
U-PB AND LU-HF ISOTOPIC SYSTEMS IN ZIRCONS AND HF-ND ISOTOPIC SYSTEMATIZATION OF THE KIMOZERO KIMBERLITES (KARELIA).
}

\author{
Lokhov K.I. ${ }^{*}$, Lepekhina E.N. ${ }^{* *}$, Kapitonov I.N. ${ }^{* *}$, Polekhovsky Yu.S. ${ }^{*}$, Bogomolov E.S..*** Sergeev S.A.** \\ * St.-Petersburg State University,geological faculty, St.-Petersburg, Russia; \\ ** VSEGEI St.-Petersburg, Russia; *** IPGG RAS, St.-Petersburg, Russia. \\ Kirill_Lokhov@vsegei.ru
}

The Kimozero kimberlite body is situated on the Onega structure of the Baltic shield. Kimberlite type rocks are intruding Paleoproterozoic vocanic and sedimetary rocks of the Ludikovy unit with the age 2040-1980 Ma. Geological, geochemical and petrographic data sow that in Kimozero body can be found at least three generations of kimberlite rocks: kimberlites of the first generation (relics in breccias), the second generation (main part of breccias) and tuffs, so one can suggest multistage magmatic episodes of its formation (Dubovikova, Polekhovsky 2009). The existing isotopic data show evidence of Protherozoic age of some individual grains of zircons which are present in these rocks (Samsonov, e.a., 2009).

Isotopic investigation was carried out in Center of Isotopic Research (CIR) VSEGEI by methods of local isotopic analysis: at first was studied U-Pb isotopic system by SIMS SHRIMP II with spatial resolution beam diameter $\mathrm{d}=15$ mkm and depth $\mathrm{h}=2 \mathrm{mkm}$, and then in the same locations by laser ablation LA-MCICPMS Finnigan Neptune/DUV-193 with $\mathrm{d}=40 \mathrm{mkm}$ and $\mathrm{h}=30-40 \mathrm{mkm}$, following (Lokhov, e.a., 2009b). For isotopic Hf-Nd systematization the data on $\mathrm{Sm}-\mathrm{Nd}$ isotopic system in kimberlites were also obtained in CIR VSEGEI.

In Kimozero kimberlites we have found a number of zircons with U-Pb age from 150 to 2545 Ma (SIMS SHRIMP II). According to low uranium concentration (3-16 ppm) and morphology, only zircon grains with measured U$\mathrm{Pb}$ age 1850-2070 Ma, can be considered as magmatic kimberlite. These zircons have concordant $\mathrm{U}-\mathrm{Pb}$ ages, and for the array of $\mathrm{U}-\mathrm{Pb}$ data can be obtained estimation of concordant age of kimberlite crystallization $2004 \pm 41$ Ma. From other side U-Pb dating by ID TIMS of individual grains of supposed magmatic kimberlite genesis gave estimation $1986 \pm 4$ Ma (Samsonov, e.a., 2009). Geochemical peculiarities of kimberlite zircons $\left({ }^{177} \mathrm{Lu} /{ }^{176} \mathrm{Hf}<0.0001\right)$ (Nowell, e.a., 2004), give possibility of their robust determination, even in case of presence in kimberlite object as captured, so metamorphic zircon grains. Lu-Hf isotopic investigation of zircons from Kimozero kimberlites have shown, that only zircons with measured U-Pb age 1850-2070 Ma can be classified as magmatic kimberlite ones (fig.1).

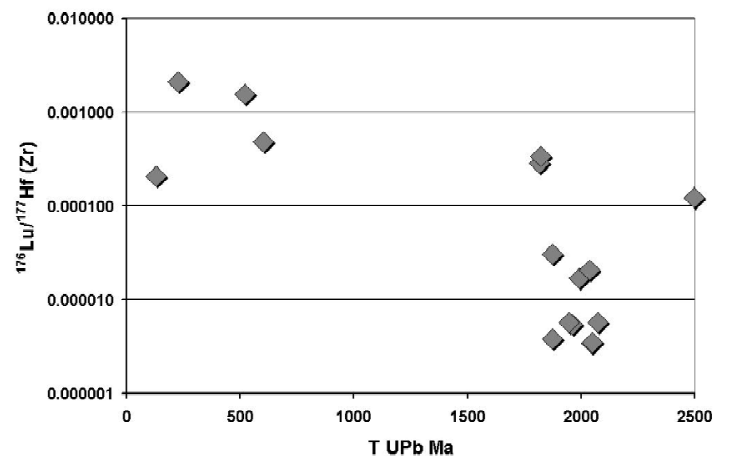

Fig. 1. Values of Lu/Hf ratios in zircons from the Kimozero kimberlites. 


\section{0 $^{\text {th }}$ International Kimberlite Conference, Bangalore - 2012}

Hf-Nd isotopic systematization give possibility for robust identification of genesis of individual zircon grains (Lokhov, e.a., 2009b) and exhibits, that zircons with age near $2500 \mathrm{Ma}$ are captured, and zircons with age in the range $130-$ $600 \mathrm{Ma}$ are metamorphic (fig.2). Metamorphic zircons with the same range of Phanerozoic ages were found in majority of Paleoproterozoic rocks of the Onega depression (Goltsin, e.a., 2010). To magmatic zircons on this plot can be attributed only those, which are belonging to correlation for magamtic rocks - "terrestrial array". Magmatic zircons can be subdivided into four groups with measured U-Pb age: 1815-1825, 1870-1875, 1920-1975 and 2000-2070 Ma. Each of these groups is characterized by specific and in series increasing parameter åHf(T) (fig.2.). Zircons of the first group mainly have ${ }^{177} \mathrm{Lu} /{ }^{176} \mathrm{Hf}>0.0001$ (fig.1), hence, are not kimberlitic. The zircons of last three groups cannot be correlated with any known group of kimberlites by $\mathrm{Hf}-\mathrm{Nd}$ systematization in (Nowell, e.a., 2004) (fig.2). Them are occupying some intermediate position, and are most close to the field of kimberlites of transitional type, which are considered to be generated by relatively enriched deep source. There is a clear regularity: as younger is the group

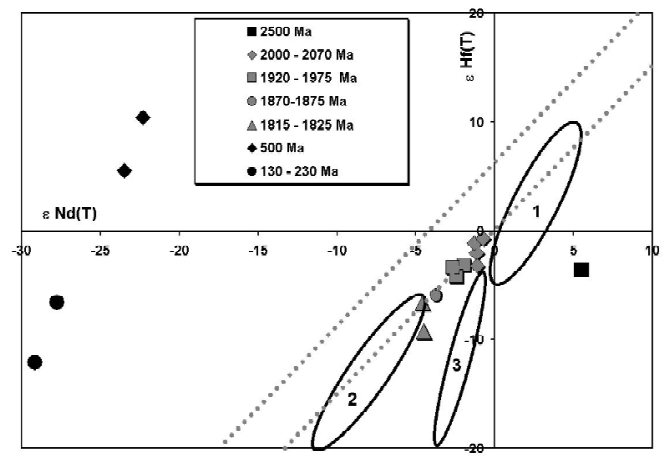

Fig.2. Isotopic Hf-Nd systematization of the Kimozero kimberlites. Gray dotted lines are marking correlation for magmatic rocks "terrestrial array", black ellipses - fields of known kimberlites by (Nowell, e.a., 2004): 1- first type, 2- second type, 3- transitional type. of zircons, so them demonstrate lower values of $\varepsilon H f(T)$ (fig.2.).

The source of captured zircon with age near $2500 \mathrm{Ma}$, according to negative åHf(T) value, could be rocks of lower crust. Metamorphic zircons of Phanerozoic age range demonstrate clear excess of radiogenic hafnium, usual for analogous metamorphic zircons from sedimentary and volcanic Paleoproterozoic rocks of the Onega depression.

Geological, geochemical and petrographic data sow that in Kimozero body can be found at least three generations of kimberlite rocks (Dubovikova, Polekhovsky 2009). Hence these three groups of zircons can be attributed to different generations of kimberlites. Calculation for these groups of $\mathrm{U}-\mathrm{Pb}$ data gives estimations of concordant ages of zircon crystallization: $1893 \pm 57,1975 \pm 65$ è $2048 \pm 48 \mathrm{Ma}$. Obtained data demonstrate, that the magmatic source of kimberlites suffered evolution in the time span over $150 \mathrm{Ma}$ at progressive increase of its enrichment from kimberlites of first type to transitional type ones. Effect of enrichment of the deep source in fact is virtual, and is related to evolution of isolated deep reservoir with model age relative to depleted mantle by hafnium near $2450 \mathrm{Ma}$ (fig.3). Origin of this kimberlite deep source can be correlated with time of Earyprotherozoic rifting event on the Baltic shield,

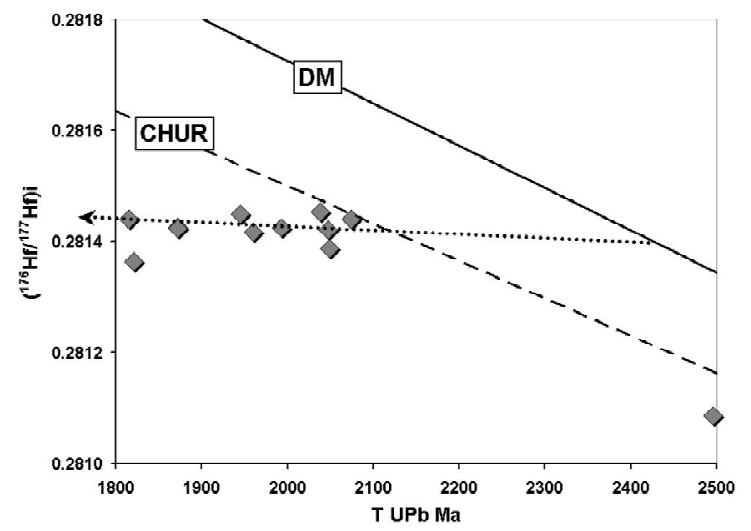

Fig..3. Evolution of Hf isotopic composition (by zircons) in the deep source of the Kimozero kimberlites. 


\section{0 $^{\text {th }}$ International Kimberlite Conference, Bangalore - 2012}

which is marked by numerous layered mafic intrusions and high magnesium basaltic series with emplacement age near 2450 Ma.

\section{References:}

Goltsin N.A., Lokhov K.I., Kapitonov I.N., e.a. Polystage transformations of high carbon Ludikovi rocks of the Onega depression. Regionalnaya Geologiya I Metallogeniya, 2010, ${ }^{14} 41$, p. 66-79. (in Russ).

Dubovikova Z.L., Plekhovsky Yu.S. Geologic peculiarities of diamond-bearing kimberlites from the Kimozero region (the Onega depression, Karelia). Regionalnaya Geologiya I Metallogeniya, 2009, ${ }^{138}$, p. 31-42.

Lokhov K.I., Kapitonov I.N., Prasolov E.M., e.a. Extremely radiogenic hafnium in zircons from Precambrian calsiphyres. Doklady Earth Sci. 2009 à, v. $425 \mathrm{~A},{ }^{1} 3$, ñ. $463-466$.
Lokhov K.I., Saltykova Ò.Å., Kapitonov I.N., e.a. Correct interpretation of $\mathrm{U}-\mathrm{Pb}$ age by zircons basing on isotopic geochemistry of hafnium and neodymium (on example of some magmatic complexes of basement of East-European platform). Regionalnaya Geologiya i Metallogeniya 38, 2009b, p.62-72 (in Russ).

Samsonov A.V., Larionova Yu.O., Salnikova E.B., e.a. Isotopic geochemistry and geochronology of Paleoproterozoic metakimberlites of Kimozero (Central Karelia). Abstr. IV Conf. On isotopic geochronology "Isotopic systems ant time of geologic processes" St.-Perersburg 2-4 June, 2009, $\mathrm{SPb} 2009$, v.2, p.158-161. (in Russ).

Nowell D.M, Pearson D.G., Bell D.R., e.a. Hf isotope systematics of Kimberlites and their Megacrysts: New constrains on their Source regions.// Journal of Petrology, 2004, aug 1, p. 1-30. 